\title{
Ecological and Microbiological Characteristics of the Jhelum River in Kashmir Himalaya
}

\author{
Shugufta Jan ${ }^{1}$, Imran Khan ${ }^{1,2}$, Gowhar H Dar ${ }^{1,2^{\star}}$, Azra N Kamili² and Irfan-ur-Rauf Tak ${ }^{\mathrm{t}}$ \\ 1Department of Environmental Science, University of Kashmir, Srinagar 190006, India \\ 2 Centre of Research for Development, University of Kashmir, Srinagar 190006, India
}

\begin{abstract}
We have assessed the density and diversity of bacterial load of the water body, the Jhelum River from Kashmir Himalaya. Bacteria were isolated and identified and some physical parameters like $\mathrm{pH}$ and temperature were measured between June-November 2011, in four sampling sites along the river. The highest bacterial count of was observed at site IV, with a cfu/ml of $2.0 \times 103$ in the month of July. The lowest viable count was at site III, with a cfu/ml of $0.3 \times 103$ in the month of November. Among different strains isolated it was found that $73 \%$ of strains isolated were Gram negative and about $27 \%$ of strains were Gram positive. It was also observed that $5 \%$ of strains were Gram positive cocci, $27 \%$ strains were Gram negative cocci, 15\% were Gram positive Bacilli and 34\% were Gram negative Bacilli. It was also found that $32 \%$ strains were cocci, $49 \%$ Bacilli, $12 \%$ strains were Diplococci and $7 \%$ strain were Streptococci. Comparative analysis of the different colonies from the four sampling sites indicates that the highest bacterial density was reached in the month of July 2011.
\end{abstract}

Keywords: Jhelum river; Ecology; Microbiology; Bacteria; Cfu/ml

\section{Introduction}

Water is always been mankind's precious resource and ninety nine percent (99\%) of the water on the planet earth is not suitable for human consumption. Most of the water is stored in groundwater. Although water is the most common and important chemical compound on earth, only $2.6 \%$ of the global water is freshwater and consequently available as potential drinking water. Availability of sufficient volume of drinking water continues to present major problems, worldwide, owing to the increasing population growth [1]. Also, other complications of highly populated areas, such as increasing amounts of waste, wastewater, and other types of contamination, also endangered access to fresh, safe drinking water [2]. This has led to the development of sophisticated techniques and systems to obtain access to new water reservoirs and to distribute water for irrigation and drinking purposes [3]. Coliforms are a broad class of bacteria that live in the digestive tracts of humans and many animals. Potable or drinking water is defined as having acceptable quality in terms of its physical, chemical, and bacteriologic characteristics so that it can be safely used for drinking and cooking. Water quality standards have been developed to minimize known chemical and microbial risks. The term "safe" drinking water does not mean risk free; it simply means risks are very small, at or below our ability to quantify them, or that water quality limits cannot be lowered further by economical water treatment processes [4]. According to the Bureau of Indian Standard (BIS) IS: 10500 Drinking Water Specification, the official standard for the bacteriological quality of drinking water is: no detectable E. coli, thermo tolerant coliform bacteria, or total coliform bacteria in $100 \mathrm{ml}$ of water. Same standards are given by World Health Organization. Many potential entry points exist, including waste disposal processes (toilet flushing), cleaning (e.g., bathing, hand washing), and indoor/outdoor sanitary activities (e.g., kitchen sink use, storm water collection, irrigation with reclaimed water), and water distribution systems (e.g., fire hydrants, storage tanks, irrigation channels) [5-7]. The intrusion of biological agents into water systems can pose serious public health risks because these agents cannot be easily detected and can remain hidden until a widespread contamination exists. Most cases with known causes have demonstrated considerable delay by authorities to perceive a risk and respond to the situation. For instance, the largest waterborne outbreak in the US resulted in massive illness among 403,000 people in Milwaukee [8]. Ford and MacKenzie noted that water was contaminated for at least 2 weeks before oocysts were identified in stool samples and water contamination was finally suspected [8]. Moreover, the management of aquatic environments requires an understanding of the important linkages between ecosystem properties and the way in which human activities can alter the interplay between the physical, chemical and biological processes that drive ecosystem functioning. Microorganisms play important roles in human daily existence such as fixation of atmospheric nitrogen, decomposition of organic waste and residues, suppression of soil-borne pathogens, degradation of toxicants including pesticides, complexion of heavy metals to limit plant uptake etc. Others, however, are harmful and are called pathogens (disease causing organisms). Some of these pathogens are able to survive both in the soil, air and water ecosystems $[9,10]$. Itah in 1999 reported that water contaminated by human or animal wastes may harbor pathogens of public health significance depending on the health of the source of the pollution and the degree of treatment [11]. Samra et al. reported the detection of Salmonella sp., Shigella sp., Staphylococcus sp., Streptococcus sp. and Escherichia coli in drinking water sources mainly due to poor water conditions, food and sewage, disposed of into the water bodies [12]. In short, every area of our environment is replete with them. The study of microbes and microbial communities in water environments is broadly known as aquatic micro biology. Microbial communities of aquatic environments include viruses, bacteria, fungi, algae and other microbes. The aquatic systems are mostly dominated by bacteria and fungi and in the natural environments micro-organisms have very specific roles with regard to the recycling of materials and purification of water.

${ }^{*}$ Corresponding author: Gowhar H. Dar, Department of Environmental Science, University of Kashmir, Srinagar, 190006 India, Tel: +91-9797124446; E-mail: dargowharhamid@gmail.com

Received April 04, 2016; Accepted May 23, 2016; Published May 30, 2016

Citation: Jan S, Khan I, Dar GH, Kamili AN, Tak IR (2016) Ecological and Microbiological Characteristics of the Jhelum River in Kashmir Himalaya. J Bacteriol Parasitol 7: 277. doi:10.4172/2155-9597.1000277

Copyright: (c) 2016 Jan S, et al. This is an open-access article distributed unde the terms of the Creative Commons Attribution License, which permits unrestricted use, distribution, and reproduction in any medium, provided the original author and source are credited. 
No substantial work has been carried out regarding the current understanding and distribution of bacterial communities in this water body. Therefore the objectives of this study were to identify and isolate the bacteria and to get an idea about the bacterial load (density and diversity) of the water.

\section{Materials and Methods}

\section{Study area and sampling sites}

he most well-known river of the Kashmir valley is Jhelum River locally known as veth. The Jhelum rises from the spring of Verinag, on the northwestern side of Pir Panjal and flows in a direction parallel to the Indus at an average elevation of 5,500 feet [13]. A total of four sites were selected randomly to access the Bacterial load of the Jhelum River as shown in (Figure 1).

Site I (Marwal): It was located about $32 \mathrm{~km}$ from the main city centre (Lal Chowk) in District Pulwama with geographical coordinate $33^{\circ} 58^{\prime}$ $45.4^{\prime \prime} \mathrm{N}$ and $74^{\circ} 54^{\prime} 16.5^{\prime \prime} \mathrm{E}$ in rural area, with lots of rural settlements on both the banks. There were also the dense trees of different species especially of Populous and Salix. The average depth of river at the site was about 1.6 meters.

Site II (Aramwari near Zero bridge): This site was located about $1.2 \mathrm{~km}$ from the Srinagar city with geographical coordinate $34^{\circ} 4^{\prime} 9.2^{\prime \prime}$ $\mathrm{N}$ and $74050^{\prime} 20.8^{\prime \prime} \mathrm{E}$, characterized by congested human population and commercial activities along both its banks. The average depth of river at the site was about 2 meters. All along its course from Marwal to Srinagar the river receives significant quantities of domestic wastes from human settlements.

Site III (Qamarwari): This site was located about $10 \mathrm{~km}$ from main city centre with geographical coordinate $34^{\circ} 05^{\prime} 35.9^{\prime \prime} \mathrm{N}$ and 740 $46^{\prime} 45.4$ " E was having both the commercial activities and residential settlements along both banks, which directly release the sewage and other solid wastes directly into the river. The average depth of river at the site was about 1.2 meters.
Site IV (Tangpora): It was located about $26 \mathrm{~km}$ from main city centre with geographical coordinates $34^{\circ} 7^{\prime} 47.1^{\prime \prime} \mathrm{N}$ and $74043^{\prime} 11^{\prime \prime} \mathrm{E}$ in rural area with human settlements along both the banks. The site was also characterized by the dense vegetation of Populous and Salix and other plants. All along the banks the land was used for the agricultural purposes.

\section{Laboratory analysis}

Surface water samples were collected monthly in sterilized bottles from June to November, 2011. The $\mathrm{pH}$ and temperature of the samples were recorded on the spot with the help of thermometer and Digital $\mathrm{pH}$ meter. The water samples were mixed with sterile distilled water and a series of dilutions were performed. From each dilution, $0.1 \mathrm{ml}$ inoculum was poured onto nutrient agar medium and incubated at $28 \pm$ $2^{\circ} \mathrm{C}$ for 1 week to assess the growth of colonies [14-21]. Purified isolates were used as stocks for further morphological. Bacterial films were prepared from each purified isolate and stained with Gram's stain, then examined under the bright field microscope with the oil immersion lens [22]. The number of colonies counted was expressed as $\mathrm{cfu} / \mathrm{ml}$ and were calculated by using the formula:

$\mathrm{cfu} / \mathrm{ml}=\mathrm{n} \times \mathrm{d}$

Where: $\mathrm{n}=$ number of colonies; $\mathrm{d}=$ dilution factor $=1 /$ dilution

\section{Results}

Different types of colonies were obtained during the study period. Some colonies were circular, some irregular and a few colonies were Rhizoid and Filamentous (Table 1). Cocci, bacilli, etc. are different morphological forms of bacteria. A total of 41 strains of bacteria were isolated from the four sites during the study. The different colonies obtained during the study were tested for gram's stain and subsequently were examined under microscope to determine the Grams nature. The strains isolated with varying colony morphology and their Gram's tests shown in Table 1 were given codes ranking from B1 to B41. Most of the colonies were circular, Entire, and flat in appearance, margin and elevation respectively. In addition to this circular, Entire and convex

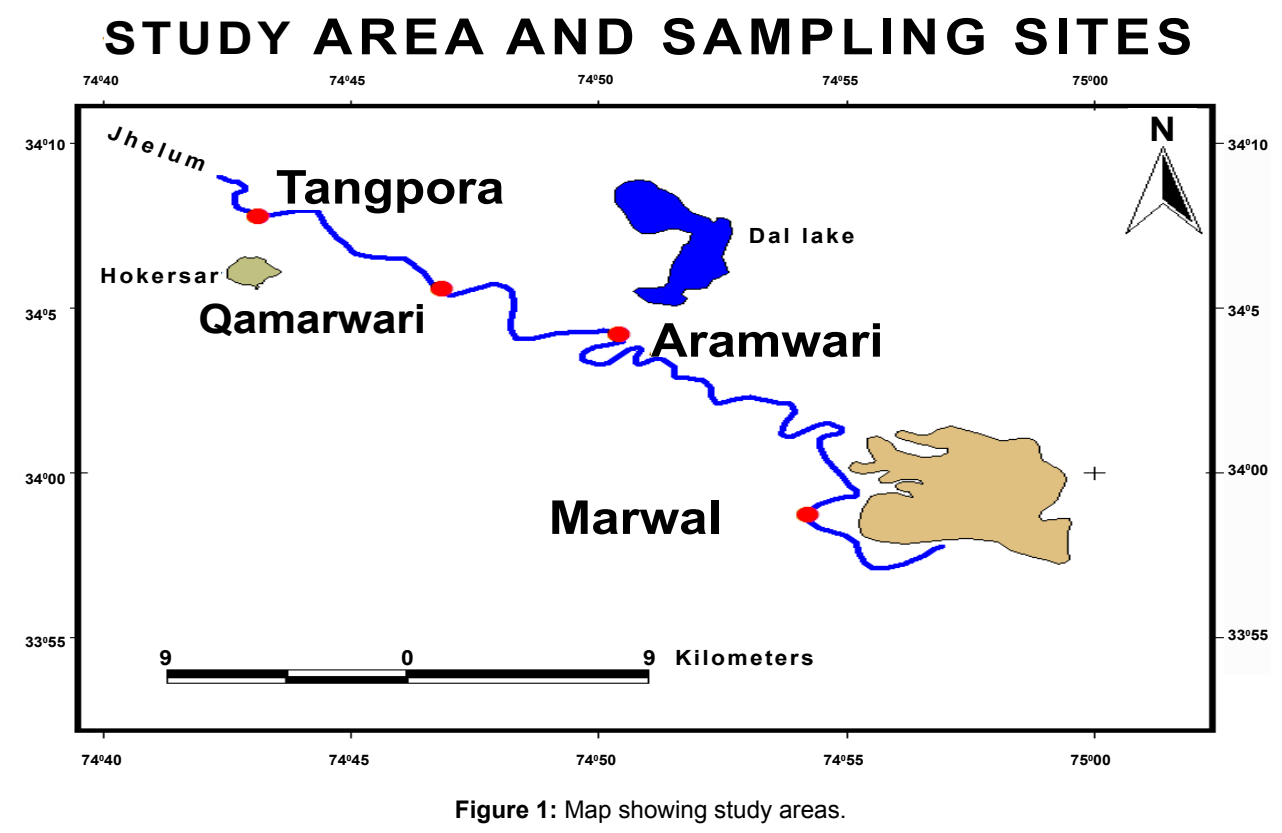




\begin{tabular}{|c|c|c|c|c|c|c|c|}
\hline $\begin{array}{l}\text { S. } \\
\text { No. }\end{array}$ & Appearance & Margin & Elevation & Color & $\begin{array}{c}\text { Grams } \\
\text { reaction }\end{array}$ & $\begin{array}{c}\text { Cell } \\
\text { shape }\end{array}$ & $\begin{array}{c}\text { Assigned } \\
\text { name }\end{array}$ \\
\hline 1. & Circular & Entire & Flat & White & -ve & C & $\mathrm{B}_{1}$ \\
\hline 2. & Circular & Entire & Flat & Yellow & $+v e$ & B & $\mathrm{B}_{2}$ \\
\hline 3. & Irregular & Undulate & Flat & Cream & -ve & B & $\mathrm{B}_{3}$ \\
\hline 4. & Circular & Entire & Flat & Cream & $-v e$ & B & $\mathrm{B}_{4}$ \\
\hline 5. & Rhizoid & Filamentous & Flat & Yellow & -ve & B & $\mathrm{B}_{5}$ \\
\hline 6. & Irregular & Undulate & Raised & Cream & -ve & C & $\mathrm{B}_{6}$ \\
\hline 7. & Irregular & Undulate & Flat & Yellow & $+\mathrm{ve}$ & B & $\mathrm{B}_{7}$ \\
\hline 8. & Filamentous & Filamentous & Flat & Cream & $+v e$ & B & $\mathrm{B}_{8}$ \\
\hline 9. & Irregular & Undulate & Raised & Yellow & -ve & C & $\mathrm{B}_{9}$ \\
\hline 10 & Irregular & Undulate & Flat & Yellow & $-v e$ & C & $\mathrm{B}_{10}$ \\
\hline 11 & Irregular & filamentous & Flat & Yellow & -ve & C & $B_{11}$ \\
\hline 12 & Irregular & Undulate & Flat & Cream & -ve & C & $\mathrm{B}_{12}$ \\
\hline 13 & Irregular & Undulate & Flat & White & $-v e$ & B & $B_{13}$ \\
\hline 14 & Circular & Entire & Raised & Cream & $+v e$ & B & $\mathrm{B}_{14}$ \\
\hline 15 & Rhizoid & Filamentous & Flat & White & -ve & C & $B_{15}$ \\
\hline 16 & Circular & Undulate & Raised & Cream & $+\mathrm{ve}$ & C & $\mathrm{B}_{16}$ \\
\hline 17 & Irregular & Filamentous & Raised & Cream & +ve & $\mathrm{DC}$ & $\mathrm{B}_{17}$ \\
\hline 18 & Circular & Filamentous & Flat & Yellow & -ve & C & $\mathrm{B}_{18}$ \\
\hline 19 & Rhizoid & Filamentous & Flat & Cream & -ve & B & $B_{19}$ \\
\hline 20 & Irregular & Lobate & Flat & Cream & -ve & B & $\mathrm{B}_{20}$ \\
\hline 21 & Irregular & Lobate & Raised & Cream & -ve & C & $\mathrm{B}_{21}$ \\
\hline 22 & Circular & Entire & Elevated & White & $-v e$ & B & $\mathrm{B}_{22}$ \\
\hline 23 & Circular & Entire & Flat & Orange & $-v e$ & C & $\mathrm{B}_{23}$ \\
\hline 24 & Filamentous & Filamentous & Flat & White & $+v e$ & B & $\mathrm{B}_{24}$ \\
\hline 25 & Circular & Undulate & Raised & Cream & $-v e$ & $\mathrm{DC}$ & $\mathrm{B}_{25}$ \\
\hline 26 & Irregular & Lobate & Flat & White & $+v e$ & B & $\mathrm{B}_{26}$ \\
\hline 27 & Circular & Entire & Convex & White & $-v e$ & $\mathrm{DC}$ & $\mathrm{B}_{27}$ \\
\hline 28 & Irregular & Filamentous & Flat & White & $+\mathrm{ve}$ & SC & $\mathrm{B}_{28}$ \\
\hline 29 & Circular & Entire & Convex & Cream & $-v e$ & B & $\mathrm{B}_{29}$ \\
\hline 30 & Filamentous & Undulate & Flat & Yellow & $+v e$ & C & $\mathrm{B}_{30}$ \\
\hline 31 & Circular & Entire & Elevated & White & -ve & $\mathrm{DC}$ & $\mathrm{B}_{31}$ \\
\hline 32 & Circular & Entire & Raised & Cream & -ve & SC & $\mathrm{B}_{32}$ \\
\hline 33 & Filamentous & Filamentous & Convex & Cream & -ve & $\mathrm{DC}$ & $\mathrm{B}_{33}$ \\
\hline 34 & Irregular & Undulate & Raised & Cream & $-v e$ & B & $\mathrm{B}_{34}$ \\
\hline 35 & Irregular & Lobate & Flat & Cream & $-v e$ & B & $\mathrm{B}_{35}$ \\
\hline 36 & Circular & Entire & Convex & Yellow & $-v e$ & C & $\mathrm{B}_{36}$ \\
\hline 37 & Filamentous & Elevate & Flat & Cream & $+v e$ & $\mathrm{DC}$ & $B_{37}$ \\
\hline 38 & Circular & Lobate & Flat & Yellow & -ve & B & $\mathrm{B}_{38}$ \\
\hline 39 & Circular & Filamentous & Flat & White & -ve & B & $\mathrm{B}_{39}$ \\
\hline 40 & Rhizoid & Lobate & Flat & Cream & -ve & B & $\mathrm{B}_{40}$ \\
\hline 41 & Circular & Curved & Flat & White & $-v e$ & $\mathrm{SC}$ & $\mathrm{B}_{41}$ \\
\hline
\end{tabular}

$C=$ Cocci, $B=$ Bacilli, $D C=$ Diplococi, $S C=$ Streptococci

Table 1: Colony morphology and microscopic examination of isolates from four sites.

colonies were also isolated. Further the strains were tested for Gram's reaction and it was found maximum strains were Gram negative. After microscopic examination $32 \%$ strains were Cocci, $49 \%$ were bacilli and the rest of the strains were diplococci and streptococci. The total and individual colony count of different isolates of bacteria isolated from different study sites during the study period are shown in Table 2 . The total isolate count reveals that the highest isolate count was B4 $(\mathrm{n}=149)$ for all sites followed by B1 with $148 ; \mathrm{B} 3$ with $115 ; \mathrm{B} 18$ with $87 ; \mathrm{B} 10$ with $83 ; \mathrm{B} 14$ with $72 ; \mathrm{B} 26$ with $62 ; \mathrm{B} 11$ with 52;B6 and B7 with 49 each;B25 with 48 ; B29 with $45 ; \mathrm{B} 27$ with $44 ; \mathrm{B} 16$ with $43 ; \mathrm{B} 8$ with $41 ; \mathrm{B} 31$ with $40 ; \mathrm{B} 5$ with $39 ; \mathrm{B} 15$ with $37 ; \mathrm{B} 12$ with $36 ; \mathrm{B} 20$ with $34 ; \mathrm{B} 22$ and $\mathrm{B} 33$ with 33 each;B30 with $32 ; \mathrm{B} 32$ with $28 ; \mathrm{B} 38$ with $27 ; \mathrm{B} 13$ and B17 with 25 each;B28 with 24;B19 with 23;B39 with 21;B9 and B35 with 19 each;B21 with 15;B24 with 14;B23 and B34 with 13 each;B37 and B41 with 9 each;B36 with $8 ; \mathrm{B} 40$ with 7 . The individual colony count of different

\begin{tabular}{|c|c|c|c|c|c|}
\hline \multirow{2}{*}{$\begin{array}{l}\text { Isolate } \\
\text { number }\end{array}$} & \multicolumn{4}{|c|}{ Sites } & \multirow[b]{2}{*}{ TOTAL } \\
\hline & Site I & Site II & Site III & Site IV & \\
\hline $\mathrm{B}_{1}$ & 38 & 44 & 30 & 36 & 148 \\
\hline $\mathrm{B}_{2}$ & 52 & 24 & 42 & 28 & 146 \\
\hline $\mathrm{B}_{3}$ & 28 & 23 & 38 & 26 & 115 \\
\hline $\mathrm{B}_{4}$ & 32 & 44 & 40 & 33 & 149 \\
\hline $\mathrm{B}_{5}$ & 3 & 11 & 15 & 10 & 39 \\
\hline $\mathrm{B}_{6}$ & 20 & 05 & 06 & 18 & 49 \\
\hline $\mathrm{B}_{7}$ & 14 & 09 & 07 & 19 & 49 \\
\hline $\mathrm{B}_{8}$ & 16 & 09 & 13 & 03 & 41 \\
\hline $\mathrm{B}_{9}$ & 4 & 09 & 04 & 02 & 19 \\
\hline $\mathrm{B}_{10}$ & 16 & 30 & 13 & 24 & 83 \\
\hline $\mathrm{B}_{11}$ & 11 & 10 & 05 & 26 & 52 \\
\hline $\mathrm{B}_{12}$ & 11 & 23 & 02 & 0 & 36 \\
\hline $\mathrm{B}_{13}$ & 10 & 13 & 02 & 0 & 25 \\
\hline $\mathrm{B}_{14}$ & 08 & 03 & 39 & 22 & 72 \\
\hline $\mathrm{B}_{15}$ & 2 & 03 & 24 & 08 & 37 \\
\hline $\mathrm{B}_{16}$ & 10 & 12 & 15 & 06 & 43 \\
\hline $\mathrm{B}_{17}$ & 09 & 04 & 02 & 10 & 25 \\
\hline $\mathrm{B}_{18}$ & 15 & 11 & 18 & 43 & 87 \\
\hline $\mathrm{B}_{19}$ & 02 & 03 & 12 & 06 & 23 \\
\hline $\mathrm{B}_{20}$ & 07 & 08 & 10 & 09 & 34 \\
\hline $\mathrm{B}_{21}$ & 08 & 0 & 07 & 0 & 15 \\
\hline $\mathrm{B}_{22}$ & 08 & 08 & 09 & 08 & 33 \\
\hline $\mathrm{B}_{23}$ & 03 & 03 & 03 & 04 & 13 \\
\hline $\mathrm{B}_{24}$ & 0 & 03 & 08 & 03 & 14 \\
\hline $\mathrm{B}_{25}$ & 11 & 09 & 03 & 25 & 48 \\
\hline $\mathrm{B}_{26}$ & 04 & 11 & 27 & 20 & 62 \\
\hline $\mathrm{B}_{27}$ & 03 & 0 & 16 & 25 & 44 \\
\hline $\mathrm{B}_{28}$ & 01 & 05 & 06 & 12 & 24 \\
\hline $\mathrm{B}_{29}$ & 06 & 07 & 17 & 15 & 45 \\
\hline $\mathrm{B}_{30}$ & 05 & 06 & 09 & 12 & 32 \\
\hline $\mathrm{B}_{31}$ & 07 & 14 & 08 & 11 & 40 \\
\hline $\mathrm{B}_{32}$ & 07 & 05 & 11 & 05 & 28 \\
\hline $\mathrm{B}_{33}$ & 01 & 02 & 16 & 14 & 33 \\
\hline $\mathrm{B}_{34}$ & 05 & 0 & 03 & 05 & 13 \\
\hline $\mathrm{B}_{35}$ & 05 & 03 & 01 & 10 & 19 \\
\hline $\mathrm{B}_{36}$ & 01 & 04 & 0 & 03 & 08 \\
\hline $\mathrm{B}_{37}$ & 03 & 01 & 01 & 04 & 09 \\
\hline $\mathrm{B}_{38}$ & 03 & 12 & 03 & 09 & 27 \\
\hline $\mathrm{B}_{39}$ & 14 & 02 & 02 & 03 & 21 \\
\hline $\mathrm{B}_{40}$ & 03 & 02 & 0 & 02 & 07 \\
\hline $\mathrm{B}_{41}$ & 01 & 06 & 02 & 0 & 09 \\
\hline
\end{tabular}

Table 2: Total isolate count of four different sites.

bacterial isolates given in Table 2, reveals that isolate B2 was having the highest number of colonies (52) at site I followed by B1, B4,B3 and others. Among the different isolates obtain, maximum $\mathrm{cfu} / \mathrm{ml}(2.1 \times$ 102) was found in the month of July at site IV (Table 3 and Figure 2). During the study the water temperature and $\mathrm{pH}$ recorded at the four sites as shown in Table 3 reveals that a maximum water temperature $\left(22^{\circ} \mathrm{C}\right)$ was at site IV in July while it was minimum $\left(5.8^{\circ} \mathrm{C}\right)$ at site IV in November. Among different strains it was found that $73 \%$ of strains isolated were Gram negative and about $27 \%$ of strains were Gram positive (Table 4 and Figure 3). It was also observed that $5 \%$ of strains were Gram positive Cocci, 27\% strains were Gram negative Cocci, 15\% were Gram positive Bacilli and 34\% were Gram negative Bacilli (Table 5 and Figure 4). It was also found that $32 \%$ strains were Cocci, $49 \%$ Bacilli, 12\% strains were Diplococci and 7\% strain were Streptococci (Figure 5). 
Citation: Jan S, Khan I, Dar GH, Kamili AN, Tak IR (2016) Ecological and Microbiological Characteristics of the Jhelum River in Kashmir Himalaya. J Bacteriol Parasitol 7: 277. doi:10.4172/2155-9597.1000277

Page 4 of 6

\begin{tabular}{|c|c|c|c|c|c|c|c|c|c|c|c|c|c|c|c|c|}
\hline \multirow{2}{*}{ Site } & \multicolumn{4}{|c|}{ June } & \multicolumn{4}{|c|}{ July } & \multicolumn{4}{|c|}{ Oct. } & \multicolumn{4}{|c|}{ Nov. } \\
\hline & CC & cfu/ml & $\mathrm{pH}$ & $\mathrm{T}\left({ }^{\circ} \mathrm{C}\right)$ & CC & cfu/ml & pH & $T$ & CC & cfu/ml & $\mathrm{pH}$ & $\mathrm{T}\left({ }^{\circ} \mathrm{C}\right)$ & CC & cfu/ml & $\mathrm{pH}$ & $\mathrm{T}\left({ }^{\circ} \mathrm{C}\right)$ \\
\hline Site I & 132 & $1.3 \times 10^{3}$ & 7.6 & 17 & 149 & $1.5 \times 10^{3}$ & 7.6 & 20.16 & 54 & $0.5 \times 10^{3}$ & 7.1 & 11 & 63 & $0.6 \times 10^{3}$ & 7.0 & 6.0 \\
\hline Site II & 140 & $1.4 \times 10^{3}$ & 7.8 & 19.1 & 153 & $1.5 \times 10^{3}$ & 7.7 & 19 & 61 & $0.6 \times 10^{3}$ & 7.1 & 11.9 & 48 & $0.5 \times 10^{3}$ & 7.1 & 6.6 \\
\hline Site III & 184 & $1.8 \times 10^{3}$ & 7.7 & 21.7 & 194 & $1.9 \times 10^{3}$ & 7.7 & 19 & 86 & $0.9 \times 10^{3}$ & 7.0 & 12.3 & 25 & $0.3 \times 10^{3}$ & 7.1 & 6.2 \\
\hline Site IV & 141 & $1.4 \times 10^{3}$ & 7.7 & 21 & 198 & $2.0 \times 10^{3}$ & 7.8 & 22 & 104 & $1.4 \times 10^{3}$ & 7.2 & 11.2 & 57 & $0.6 \times 10^{3}$ & 7.1 & 5.8 \\
\hline
\end{tabular}

$C C=$ Colony Count $;$ cfu =colony forming unit $T\left({ }^{\circ} \mathrm{C}\right)=$ Temperature

Table 3: Colony count, cfu/ml at the four sites

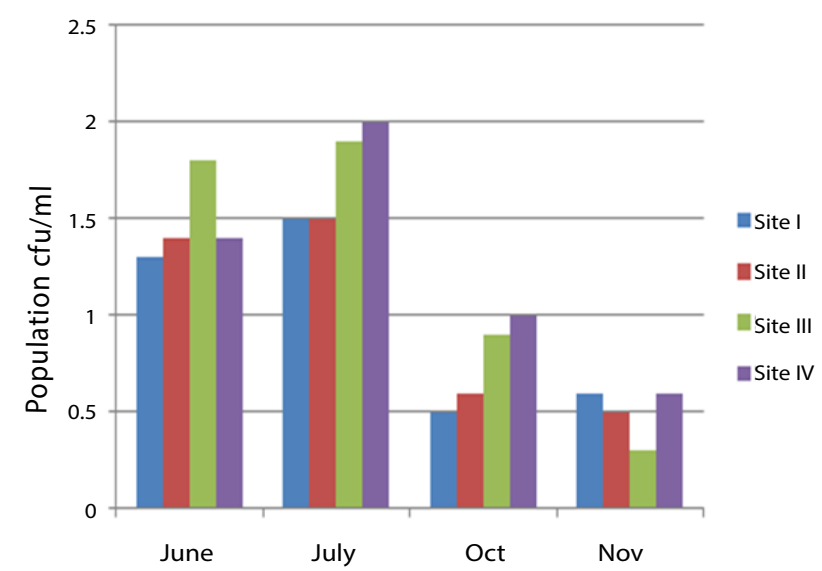

Figure 2: Graphical representation of colony counts (cfu/ml) at the four different sampling sites.

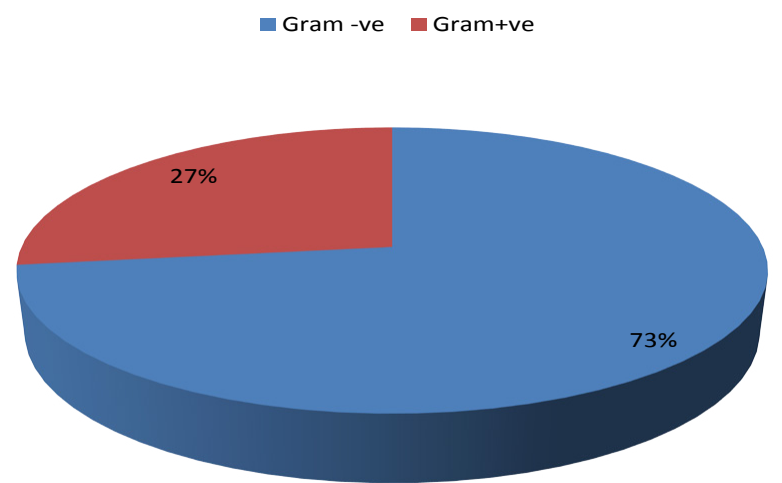

Figure 3: Contribution of G+ve and G-ve bacteria during the study.

\section{Discussion}

The total monthly bacterial population as given in Table 3 and Figure 2 showing that the number of bacterial count decreased from July to November 2011. This decrease in the bacterial count may be attributed to the difference in various biotic and abiotic factors that have been found to influence the density and diversity of bacterial communities [17,18]. Another reason for the decrease of bacterial population may be attributed to decreasing $\mathrm{pH}$ because the $\mathrm{pH}$ varied between 7.2 to 7.8 . The present study is confirmed by the findings of Lauber et al. who indicated significance of $\mathrm{pH}$ and temperature for the growth of bacterial colonies [23]. Similarly, Dar et al. in 2012 observed that bacterial count declines in October and November with decrease in $\mathrm{pH}$ and temperature in soils [18]. The bacterial count was highest at site IV $(2.0 \times 103) \mathrm{cfu} / \mathrm{ml}$ in the month of July compared

\begin{tabular}{|c|c|c|c|c|}
\hline S.NO. & $\begin{array}{c}\text { Isolate } \\
\text { type }\end{array}$ & Gram's reaction & Percentage & Cell shape \\
\hline 1 & $\mathrm{~B}_{2}$ & $+v e$ & \multirow{11}{*}{ 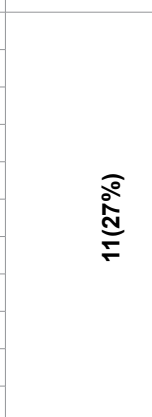 } & B \\
\hline 2 & $\mathrm{~B}_{7}$ & $+v e$ & & B \\
\hline 3 & $\mathrm{~B}_{8}$ & $+v e$ & & B \\
\hline 4 & $\mathrm{~B}_{14}$ & $+v e$ & & B \\
\hline 5 & $\mathrm{~B}_{16}$ & $+v e$ & & C \\
\hline 6 & $B_{17}$ & $+v e$ & & $\mathrm{DC}$ \\
\hline 7 & $B_{24}$ & $+v e$ & & B \\
\hline 8 & $\mathrm{~B}_{26}$ & $+v e$ & & B \\
\hline 9 & $\mathrm{~B}_{28}$ & $+v e$ & & SC \\
\hline 10 & $\mathrm{~B}_{30}$ & $+v e$ & & C \\
\hline 11 & $\mathrm{~B}_{37}$ & $+v e$ & & $\mathrm{DC}$ \\
\hline 12 & $\mathrm{~B}_{1}$ & -ve & \multirow{30}{*}{$\begin{array}{l}\overline{\mathrm{o}} \\
\stackrel{\tilde{c}}{\stackrel{0}{0}}\end{array}$} & $\mathrm{C}$ \\
\hline 13 & $\mathrm{~B}_{3}$ & -ve & & B \\
\hline 14 & $\mathrm{~B}_{4}$ & -ve & & B \\
\hline 15 & $\mathrm{~B}_{5}$ & -ve & & B \\
\hline 16 & $\mathrm{~B}_{6}$ & -ve & & C \\
\hline 17 & $\mathrm{~B}_{9}$ & -ve & & C \\
\hline 18 & $B_{10}$ & -ve & & C \\
\hline 19 & $B_{11}$ & -ve & & C \\
\hline 20 & $B_{12}$ & -ve & & C \\
\hline 21 & $\mathrm{~B}_{13}$ & -ve & & B \\
\hline 22 & $\mathrm{~B}_{15}$ & -ve & & C \\
\hline 23 & $\mathrm{~B}_{18}$ & -ve & & C \\
\hline 24 & $\mathrm{~B}_{19}$ & -ve & & B \\
\hline 25 & $\mathrm{~B}_{20}$ & -ve & & B \\
\hline 26 & $\mathrm{~B}_{21}$ & -ve & & B \\
\hline 27 & $\mathrm{~B}_{22}$ & -ve & & C \\
\hline 28 & $\mathrm{~B}_{23}$ & -ve & & B \\
\hline 29 & $\mathrm{~B}_{25}$ & -ve & & C \\
\hline 30 & $\mathrm{~B}_{27}$ & -ve & & $\mathrm{DC}$ \\
\hline 31 & $\mathrm{~B}_{29}$ & -ve & & B \\
\hline 32 & $\mathrm{~B}_{31}$ & -ve & & $\mathrm{DC}$ \\
\hline 33 & $\mathrm{~B}_{32}$ & -ve & & SC \\
\hline 34 & $\mathrm{~B}_{33}$ & -ve & & $\mathrm{DC}$ \\
\hline 35 & $B_{34}$ & -ve & & $B$ \\
\hline 36 & $\mathrm{~B}_{35}$ & -ve & & B \\
\hline 37 & $\mathrm{~B}_{36}$ & -ve & & C \\
\hline 38 & $\mathrm{~B}_{38}$ & -ve & & B \\
\hline 39 & $\mathrm{~B}_{39}$ & -ve & & B \\
\hline 40 & $\mathrm{~B}_{40}$ & -ve & & B \\
\hline 41 & $\mathrm{~B}_{41}$ & -ve & & SC \\
\hline \multicolumn{3}{|r|}{ Total } & \multicolumn{2}{|c|}{$41(100 \%)$} \\
\hline
\end{tabular}

Table 4: Percentage of gram +ve and -ve isolates.

to the site III $(0.3 \times 103) \mathrm{cfu} / \mathrm{ml}$ in the month of November, which may be attributed to temperature. Similar results were found by Murphy and Dar et al. 2011, who reported that bacteria grow fast at higher temperature and the growth rate slows down dramatically at 
Gram +ve coci Gram -ve coci Gram + ve bacilli

Gram -ve bacilli others

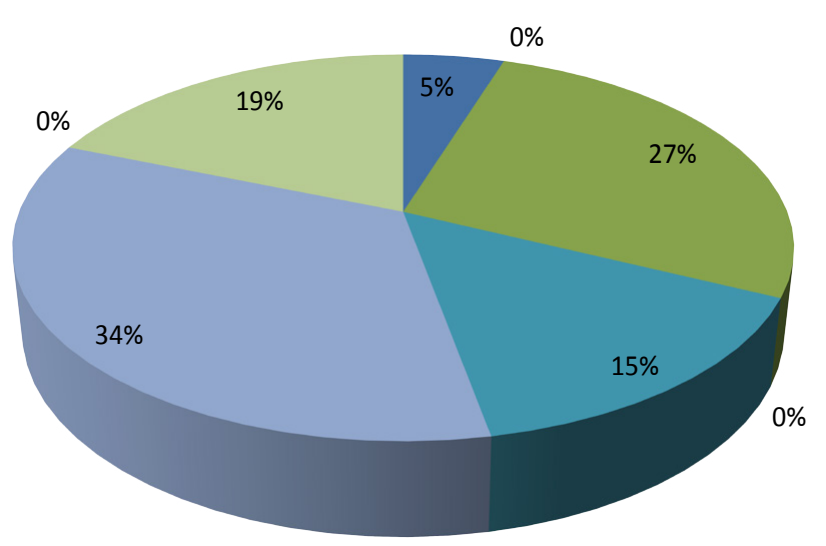

$0 \%$

Figure 4: Contribution of G+ve, and G-ve Cocci and Bacilli during this study.

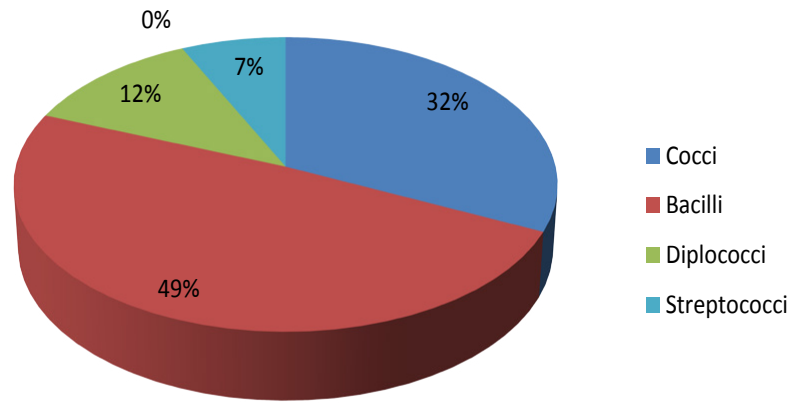

Figure 5: Contribution of different strains of Bacteria during this study.

low temperature $[17,24]$. It was found that maximum strains were Gram negative after microscopic examination (32\% were Cocci, $49 \%$ were bacilli). The results of our study are in consonance with some recent studies on the bacteriological analysis of water and soil in the Kashmir valley $[19,21,25]$. Also the anthropogenic pressure along the catchments has adversely affected the quality of lotic water systems of Kashmir [13]. The Presence of Gram negative Cocci are of much concern because of their pathogenicity resulting in diseases in humans and the abundance of the gram negative bacteria observed at different sites may be attributed to the increased addition of the sewage and other animal excreta into the river [17]. The aquatic environment is considered a hot-spot for horizontal gene transfer, and lake sediments offer the opportunity for reconstructing the pollution history and evaluating the impacts. The contamination of sediments by untreated or partially treated effluent water can affect the quality of ecosystem [26]. As the gram negative bacteria have a reservoir in the intestines of man and other warm blooded animals, are excreted in feces and are known to survive in the environment but do not reproduce [27]. Thus, the contamination of Water bodies by untreated or partially treated effluent water can affect the quality of ecosystem.

\begin{tabular}{|c|c|c|c|c|c|}
\hline S. No & Isolate type & Gram's reaction & Percentage & & Cell shape \\
\hline 1 & $\mathrm{~B}_{2}$ & $+v e$ & \multirow{6}{*}{ 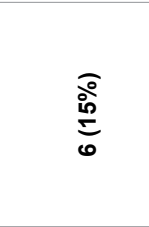 } & \multirow{20}{*}{ ஓ } & $B$ \\
\hline 2 & $\mathrm{~B}_{7}$ & $+v e$ & & & $B$ \\
\hline 3 & $\mathrm{~B}_{8}$ & $+v e$ & & & $B$ \\
\hline 4 & $\mathrm{~B}_{14}$ & $+v e$ & & & $B$ \\
\hline 5 & $\mathrm{~B}_{24}$ & $+v e$ & & & $B$ \\
\hline 6 & $\mathrm{~B}_{26}$ & +ve & & & B \\
\hline 7 & $\mathrm{~B}_{3}$ & $-v e$ & \multirow{14}{*}{ 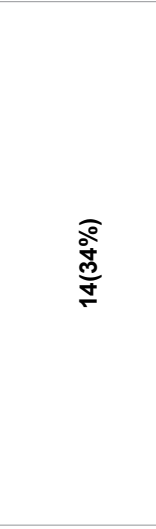 } & & B \\
\hline 8 & $\mathrm{~B}_{4}$ & $-v e$ & & & $B$ \\
\hline 9 & $\mathrm{~B}_{5}$ & $-v e$ & & & B \\
\hline 10 & $\mathrm{~B}_{13}$ & -ve & & & B \\
\hline 11 & $\mathrm{~B}_{19}$ & $-v e$ & & & $B$ \\
\hline 12 & $\mathrm{~B}_{20}$ & -ve & & & $B$ \\
\hline 13 & $\mathrm{~B}_{21}$ & $-v e$ & & & $B$ \\
\hline 14 & $\mathrm{~B}_{23}$ & $-v e$ & & & $B$ \\
\hline 15 & $\mathrm{~B}_{29}$ & -ve & & & $B$ \\
\hline 16 & $\mathrm{~B}_{34}$ & -ve & & & $B$ \\
\hline 17 & $\mathrm{~B}_{35}$ & -ve & & & $B$ \\
\hline 18 & $\mathrm{~B}_{38}$ & -ve & & & $B$ \\
\hline 19 & $\mathrm{~B}_{39}$ & $-v e$ & & & B \\
\hline 20 & $\mathrm{~B}_{40}$ & $-v e$ & & & B \\
\hline 21 & $\mathrm{~B}_{16}$ & $+v e$ & \multirow{13}{*}{ 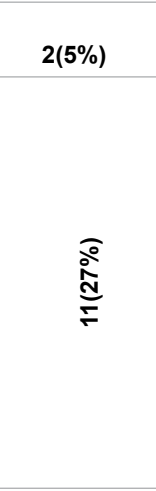 } & \multirow{13}{*}{$\begin{array}{l}\text { ஓे } \\
\text { స్ } \\
\text { ᄋ्ల }\end{array}$} & C \\
\hline 22 & $\mathrm{~B}_{30}$ & +ve & & & C \\
\hline 23 & $\mathrm{~B}_{1}$ & -ve & & & C \\
\hline 24 & $\mathrm{~B}_{6}$ & -ve & & & $C$ \\
\hline 25 & $\mathrm{~B}_{9}$ & -ve & & & $C$ \\
\hline 26 & $\mathrm{~B}_{10}$ & -ve & & & $C$ \\
\hline 27 & $\mathrm{~B}_{11}$ & $-v e$ & & & $C$ \\
\hline 28 & $\mathrm{~B}_{12}$ & $-v e$ & & & $C$ \\
\hline 29 & $\mathrm{~B}_{15}$ & -ve & & & $C$ \\
\hline 30 & $\mathrm{~B}_{18}$ & -ve & & & $C$ \\
\hline 31 & $\mathrm{~B}_{22}$ & -ve & & & $C$ \\
\hline 32 & $\mathrm{~B}_{25}$ & -ve & & & $C$ \\
\hline 33 & $\mathrm{~B}_{36}$ & -ve & & & $C$ \\
\hline 34 & $\mathrm{~B}_{17}$ & +ve & \multirow[b]{2}{*}{$2(5 \%)$} & \multirow{6}{*}{$\underset{\infty}{\stackrel{\circ}{\circ}}$} & DC \\
\hline 35 & $\mathrm{~B}_{37}$ & +ve & & & DC \\
\hline 36 & $\mathrm{~B}_{27}$ & -ve & \multirow{3}{*}{$3(7 \%)$} & & DC \\
\hline 37 & $\mathrm{~B}_{31}$ & -ve & & & DC \\
\hline 38 & $\mathrm{~B}_{34}$ & -ve & & & $\mathrm{DC}$ \\
\hline 39 & $\mathrm{~B}_{28}$ & $+v e$ & $1(2 \%)$ & & SC \\
\hline 40 & $\mathrm{~B}_{32}$ & $-v e$ & \multirow[b]{2}{*}{$2(5 \%)$} & & SC \\
\hline 41 & $\mathrm{~B}_{41}$ & -ve & & & SC \\
\hline \multicolumn{3}{|c|}{ Total } & \multicolumn{3}{|c|}{$41(100 \%)$} \\
\hline
\end{tabular}

$C=$ Cocci, $B=$ Bacilli, DC = Diplococi, SC = Streptococci.

Table 5: Percentage of different bacterial strains.

\section{Conclusions}

Among the Bacterial strains isolated and identified most of them were Gram- negative bacilli followed by Gram-negative cocci. These are of much concern because of their pathogenicity resulting in diseases in humans. Since the present study is of preliminary nature more investigation in this direction should be undertaken.

\section{References}

1. Postel S (1997) Last oasis: facing water security. Norton, New York.

2. Hunter PR, Quigley C (1998) Investigation of an outbreak of cryptospondiosis associated with treated surface water finds limits to the value of case control studies. Commun Dis Public Health 1: 234-238.

3. Hammerton C, Sherratt JG (1972) Analysis of raw, potable and Wastewater, Great Britain. 
Citation: Jan S, Khan I, Dar GH, Kamili AN, Tak IR (2016) Ecological and Microbiological Characteristics of the Jhelum River in Kashmir Himalaya. J Bacteriol Parasitol 7: 277. doi:10.4172/2155-9597.1000277

Page 6 of 6

4. Szewzyk U, Szewzyk R, Manz W, Schleifer KH (2000) Microbiological safety of drinking water. Ann Rev of Microbiol 54: 81-127.

5. Decker RG (1990) Sewer line collapse at Prince and Oracle or how not to spend Labor Day weekend. Pima County Wastewater Management Department.

6. Mark O, Wennberg C, VanKalken T, Rabbi F, Albinsson B (1998) Risk analyses for sewer system based on numerical modeling and GIS. Saf Sci 30: 99-106.

7. Choi CY, Gerba CP, Riley M (2003) Environmental dispersion of biological agents in sewer systems. Final Report, DARPA Project no. 806345617.

8. Ford TE, MacKenzie WR (2000) How safe is our drinking water? Despite technologic advances, waterborne disease is still a threat. Postgrad Med 108: $11-14$

9. Acosta CJ, Galindo CM, Kimario J, Senkoro K, Urassa H, et al. (2001) Cholera outbreak in southern Tanzania: Risk factors and patterns of transmission. $J$ Emerg Infect Dis 7: 583-587.

10. Mahfouz SA, Shaieb FM, Elzem AEK (2008) Detection and identification of groundwater bacteria in Sebha city, Libya. African J Microbial Res 2: 224-228.

11. Itah AY (1999) Studies on Vibrio species and bacteriological quality of fishes clams. J Sci Engr Tech 6: 1722-1739.

12. Samra ZQ, Snaseem M, Khan SJ, Athar MA (2009) PCR Targeting of Antibiotic Resistant Bacteria in Public Drinking Water of Lahore Metropolitan, Pakistan. Biomed Environ Sci 22: 458-463.

13. Khan I, Ali M (2013) Current Status of the Fish Fauna of River Jhelum, Kashmir 2: 694

14. Waksman SA (1922) A method of counting the number of fungi in the soil. $J$ Bact 7: 339-341.

15. Warcup JH (1950) The soil plate method for isolation of fungi from soil. Nature 166: 117-118.

16. Bandh SA, Kamili AN, Ganai BA (2011) Identification of some Penicillium species by traditional approach of morphological observation and culture. Afr J Microb Res 5: 3493-3496.
17. Dar GH, Bandh SA, Kamili AN (2011) Bacteriological analysis of soil from Yusmarg Health Resort of Kashmir Valley. Int J Curr Res 3: 53-56.

18. Dar GH, Kamili AN, Nazir R, Bandh SA, Bhat RA (2012) A Preliminary Study Of Colony Forming Units Of Bacteria From The Soils Of Yusmarg Forest, Kashmir Valley India. Int J Curr Res 4: 467-472.

19. Dar GH, Bandh SA, Kamili AN, Nazir R, Bhat RA (2013) Comparative Analysis of Different Types of Bacterial Colonies from the Soils of Yusmarg Forest Kashmir valley India. Ecologia Balkanica 5: 31-35.

20. Dar GH, Kamili AN, Nazir R, Bandh SA, Jan TR, et al. (2015) Enhanced production of $\alpha$-amylase by Penicillium chrysogenum in liquid culture by modifying the process parameters. Microb Pathog 88:10-15.

21. Fayaz F, Kamili AN, Hafiz BZ, Khan I, Dar GH (2015) Abundance and diversity of major cultivable fungal flora of River Jhelum in Kashmir Himalaya. Journal of Ecology and the Natural Environment 7: 1-6.

22. Cruickshank R, Duguid JP, Marmian BP, Swain RHA (1979) Medical Microbiol: The practice of medical Microbiol. (12thedn), Churchill Livingstone, Edinburgh London. pp: 13: 145-155.

23. Lauber CL, HanadyM, Knight R, Fierer N (2009) Pryrosequencing based assessment of soil $\mathrm{pH}$ as predictor of soil bacterial community composition at continental scale. Appl Environ Microbial 75: 5111-5120.

24. Murphy RY (2000) Pathogenic lethality validation in Ready to eat meat products. Presented at Advanced foods company, Enid, UK.

25. Shafi S, Bandh SA, Kamili AN (2011) A Preliminary Microbiological Study of Sindh, a Glacier fed River of Sonamarg Kashmir. New York Science Journal 4: 58-62.

26. Devarajan N, Laffite A, Graham ND, Meijer M, Prabakar K, et al (2015) Accumulation of Clinically Relevant Antibiotic-Resistance Genes, Bacterial Load, and Metals in Freshwater Lake Sediments in Central Europe. Environ Sci Technol 49: 6528-6537.

27. Feachem RG, Bradley BJ, Garelick H (1983) Sanitation and Disease, Health Aspects of Excreta and Wastewater Management, Chichester. John Willey and Sons. 